\title{
CHILDREN'S FUNNY REMARKS IN THE FIELD OF LINGUISTIC HUMOUR THEORY
}

\author{
Piret Voolaid
}

\begin{abstract}
The article analyses, from folkloristic and humour theoretical aspects, humorous material of children's remarks collected during the all-Estonian kindergarten folklore collection campaign held from October 2010 to January 2011.

The main focus is on this subtype of jokes as they appear in kindergarten environment and from the point of view of kindergarten teachers. The material is divided into two groups: 1) spontaneous sayings, recorded during daily activities and interaction; 2) answers to the teacher's questions, guided by her interest (the teacher may have recorded discussions on a given topic). The article aims to investigate the utterances that teachers have perceived as funny or worth recording and to analyse the theoretical mechanisms of humour they are based on.
\end{abstract}

Keywords: all-Estonian kindergarten folklore collection campaign, child language, child lore, children's funny remarks, linguistic theory of humour

We have all heard, some of us more than others, the candid and direct remarks children make that put a humorous twist on reality. Parents who witness their children growing up probably hear these remarks more often, but pre-school teachers who spend even more time with children during their waking hours than their parents also hear them a great deal. The widespread custom of writing down what children say can be regarded as part of family and pre-school lore. Children's remarks are often circulated in video, audio, and social media as a separate form of humour. Discussions of adult topics from a child's point of view as well as the imaginative linguistic creativity of children come across as sincere, genuine, and often funny. This sincere and genuine way of speaking has also brought the word lapsesuu ('child's mouth') into the Estonian language, which is used figuratively to characterise someone who speaks as frankly as a child (EKSS 2009: 55). Sounding childish can sometimes be an intentional rhetorical method, similar to the way politicians sometimes speak.

Writing down the funny things children say is a popular tradition in modern written culture, but Estonian folklorists have not carried out any detailed research on the subject to date. The main reason is that such funny remarks are associated with a specific child at the moment they are uttered, so they 
are the creations of an author, which is something that only began to receive attention in folklore a couple of decades ago. The systematic collection of childlore in Estonia began in the $1920 \mathrm{~s},{ }^{1}$ but a catalyst in research occurred after a nationwide competition in collecting school lore that took place in 1992 (see, e.g., Kõiva 1995)2. However, the rich world of children's lore has many facets that are still waiting to be analysed.

Since the autumn of 2010, I have had the opportunity to participate in the organisation of a nationwide series of Estonian language training seminars initiated by the Ministry of Education and Research as a coordinator from the Estonian Literary Museum. Writers, researchers, museum workers, and preschool educators traditionally speak at the two-day seminars now held in Tartu every year. The topics discussed include the meaning and values of language use in society and the options for using cultural heritage and folklore (language also represents the building blocks used to create folklore) in language training. At the first training seminar, I led a workshop about children's lore and the work we did prior to the seminar gave us the idea to announce a nationwide competition in collecting pre-school lore, which would be organised jointly by the Department of Folkloristics of the Estonian Literary Museum and the Estonian Folklore Archives. ${ }^{3}$ One of the responses we received to the in-depth questionnaire we sent out was over 100 pages of the cool expressions and funny remarks of children, which are the source material for this research.

The purpose of the article is to take a look at the material we received, the main research questions being: 1) how can children's jokes be defined; what is the bigger picture revealed by the phenomenon; 2) what has been perceived funny by teachers and what have they decided to write down; and 3) on which mechanisms of the theory of humour is children's humour based and which principles can be used to systematise the children's jokes that have been written down.

\section{INTERDISCIPLINARY RESEARCH OF MATERIAL}

Researchers trying to define and analyse children's jokes immediately find themselves in an interdisciplinary field. There is no doubt that the remarks that are on the borderline of language and folklore are part of a broader children's language, which is why the aspects related to the development of children's language skills and speech must be considered when their jokes are studied.

In terms of folklore, children's jokes fall into the category of funny things that have happened in real life and (language specific) stories based on humorous life events (see Hiiemäe 2014: 845). Mall Hiiemäe (ibid.) has written that 
collecting (humorous) folk tales based on individuals and influenced by real life started in the 1930s, but an earlier scientific approach and the more targeted definition of such material emerged in Estonian folklore in the 1960s. The term "lapsesuu" ('child's mouth'), which is the precursor of the term "lapsesuunaljad" (literally 'jokes from a child's mouth'; 'children's jokes'), was already used in the introduction to the first volume titled Periods of Human Life of the publication Funny Estonian Folk Tales, written by Rudolf Põldmäe in 1941:

A person becomes the butt of jokes as soon as he or she is born. Experienced observers laugh at the ignorance of those who know nothing about the emergence and development of life. There is also no way of avoiding laughter during the trials and tribulations of a child's spiritual development. This creates the so-called "lapsesuu" tales (funny folk tales from children'), which have been actively published by our former newspapers and family magazines, and which have also made their mark on funny folk tales. Types that are too literary have been excluded from this, although the issue of sources is far from resolved. On the other hand, the logic and tales of children are based on true stories that have not yet acquired the traditionalism of folklore. However, there are still many ancient motifs in this group, which have lost their sharp corners as they have become widely spread and have acquired a certain artistic form. (Põldmäe 1941: 8)

Therefore, Põldmäe documented the phenomenon and also raised the issue of authenticity and secondary literature, which was important from the viewpoint of folkloristics of the time. Also, he already pointed out the influence of media on the distribution of children's jokes. The jokes themselves (no. 15-96) have been divided into sections in the book: Children's Stupidity and Mishaps; Children's Candour; Children's Laziness, Stubbornness and Malice; Children Acting as Adults, Children's Wisdom and Shrewdness. Sigrid Schmidt (2005: 257) highlighted three types of children's jokes: 1) jokes whose heroes are usually stereotyped figures, which is the category in which she places the majority of folklore jokes; 2) jokes told by children to children and which also confront child heroes and adults; 3) actual remarks by children usually addressed to adults that adults regard as amusing though the children are serious. Whilst the children's jokes given by Põldmäe in his Funny Estonian Folk Tales mostly represent the first sub-type, the jokes written down by pre-school teachers mainly belong to the latter group. The difference from anecdotes lies in the fact that the remarks are usually not funny for children themselves, but adults see the jokes that have emerged in everyday situations as unintentional humour (see Martin 2007: 1415) or accidental humour (Nilsen \& Nilsen 2000: 6-9). 
Similar to the collection and research of childlore, the collecting and researching of children's language in Estonia also started in the 1920s. The first invitation to start writing down remarks made by children was published by Julius Mägiste in his article A Few Words about Child Language, which was published in the first issue of the Eesti Keel (Estonian Language) magazine in 1924 (Mägiste 1924). Andrus Saareste and Paul Ariste also studied child language in the 1930s (Argus 2003). The level of collecting and researching child language in present-day Estonia is professionally high and the representative corpus created on the basis of recordings of everyday speech (the first data were added in 1998 (Argus 2007)) has been logged in the international CHILDES system (Child Language Data Exchange System), which was developed in order to provide a common basis for transcribing, processing, comparing and sharing the language material collected by different researchers. The linguistic goal of such corpora is to study the problems associated with the acquisition of a first and second language, bilingualism, and various clinical problems. Several studies of how a small child learns his or her native language have been published on the basis of the corpus. In purely linguistic terms, the sub-corpus of the article also reflects the essence of the language acquisition process, the logic behind child language (repeated slips of the tongue) and the way they understand language. Against the background of said material, it also became evident that speech therapists in pre-schools write down the witty remarks made by children out of professional interest in order to analyse technical errors in speech.

Several databases of child language outside Estonia can also be used as examples. The corpus of remarks characteristic of Russian child language prepared by Russian linguist Vera Kharchenko (2012) was created as a result of a project that lasted from 2005 to 2011 . The material was collected during the extensive observation of the everyday language used by the researcher's two grandsons (born in 2003 and 2006). Kharchenko calls the corpus she created an alternative dictionary genre, which is another arsenal of the specific features of child language, which allows researchers to identify and study child language from broad interdisciplinary aspects. Kharchenko's longer-term goal is to combine her work with previously collected material to prepare a multivolume dictionary of Russian child language. The author herself proceeded from the following technical aspects in her work: the fact of word and form creation, congruency errors, wrong word stress, child's questions, child's discussions (with the emphasis on the child's opinions and beliefs), copying adults (Kharchenko 2012: 15).

The entire discourse of children's jokes must also be approached from the pedagogical angle. Once again, we are facing the fact that the humour arises from the position of adults, who keep passing on the joke and may even start using the funny linguistic form themselves. However, educationists have em- 
phasised that it is pedagogically wrong to repeat a child's speech using the words they have said incorrectly, even if they may seem funny and interesting to adults, because there is nothing interesting in them for children - they do not realise that they say them differently from adults; laughing and making fun of them will hurt and confuse them (Kraav 2007: 75). This shows that different disciplines dealing with the same research material emphasise different things.

\section{ASPECTS OF HUMOUR THEORY}

The way children experience and express things is usually turned into a story by someone else, usually a family member - parent or grandparent, older brother or sister, child-minder, pre-school teacher, etc. - who happened to witness the event. What makes these experiences worth recording is their different logic, mistakes, developments that seem interesting and emotionally valuable. Children's jokes are a part of everyday speech. They usually come across as entertaining, spontaneous, and mundane situational humour that children themselves ordinarily do not see as funny. Inside lore groups, the tales usually relate to specific children and events, but good story lines may spread outside the specific community (e.g. via collections of jokes or by being told to others as anecdotes) as anonymous jokes.

Those who collect children's remarks have called them expressions of the genius and creativity of children's way of thinking (Chukovsky 2001). The cultural and historical joke theories aimed at social aspects describe humour as a phenomenon that reflects the society and can be used to discover concealed views of what is going on in society, the contradictions or problems (Laineste 2003: 798). This means that a question we could ask in this study is to what extent is the surrounding reality reflected through the eyes of children and what can be said about the lives of children in a broader sense based on their remarks.

In a larger social and cultural context, the research of jokes based on the remarks of children is compatible with the changes in the approaches to childhood that have occurred in recent decades, in moving the emphasis from the traditional towards a more sociological approach. Due to their immaturity and incompetence, children have traditionally been regarded as beings that depend on adults, but the viewpoint of childhood sociology is child-centred - a child is an active member of society who is given a greater say and whose opinion is taken into account (Prout \& James 2005: 59). Giving attention to what children say attributes importance to the child as a personality and their opinions; it makes them heard. As the material becomes more folkloric, funny remarks have the potential to become group or family lore, which may remain part of 
the community's language for years. The gradual disappearance of the original context and personality strengthens the importance of the funny saying, which may become rooted in community slang as an especially short form of a word, or stay in circulation as a longer narrative. Funny stories may become more topical as the child grows and his or her reaction to it may be ambivalent. Jokes may become tools that support the child's identity, helping them develop their self-image and describing the child in a period of time they do not remember ("I said it like this."). These recorded remarks therefore enrich the child's knowledge of self in social situations and relationships, supporting memories of their personal past. However, it is possible that telling jokes about the child may cause embarrassment to him or her once they reach a certain age.

So-called cognitive humour theories gained considerable ground in humour studies in the 1960s and 1970s. They regard humour as a cognitive experience and find that there is some kind of objective 'real' contradiction or incongruence in a funny (verbal or non-verbal) object, which creates a moment of surprise and comes across as funny (Krikmann 2004: 6). Based on the material in hand, it is the humour in the remark that makes an event worthy of recording and sharing with others; the moment of surprise that makes a remark funny lies in the child's unexpected logic, the way in which they understand or misunderstand things, slips of the tongue that are funny in certain situations or per se, which are emotionally worthy of being written down and passed on to others. Contradictions, exaggerations, subconscious mistakes and children's genuine and sincere candour often differ from the way adults speak and surprise the listener.

Alleen Pace Nilsen and Don L. F. Nilsen (2000: 6) have divided accidental humour into linguistic (verbal) and physical. Child humour as verbal source material falls into the category of linguistic humour, which is why it has a secure place in linguistic theories of humour. In addition to children's remarks, such accidental humour also covers the funny remarks made by reporters (sports commentators), funny quotes from the works of students (e.g. essays, research papers) and many others that all have relatively universal bases. Child lore can also be adequately researched in light of the General Theory of Verbal Humour (GTVH) of Salvatore Attardo and Victor Raskin (1991), which generally lies in the hierarchic representation model of six knowledge resources. In brief, the levels of knowledge resources are: 1) script opposition (SO), which was taken over from Raskin's (1985) earlier semantic theory of humour and which states that a joke must be compatible with two different scripts and these in turn must be in opposition to each other to a certain extent; 2) logical mechanism (LM), which when breached causes discrepancies and false analogies that evoke humour; 3) situation (SI), which forms the contextual foundation of the joke and includes activities, participants, objects, etc.; 4) target (TA) or the butt 
of the joke; 5) narrative strategy (NS) or the genre in which the joke works (e.g. anecdote, proverb, riddle), in this case longer or shorter texts that briefly describe activities and are presented as monologues or dialogues where the main emphasis is on the child's remark; 6) language (LA) or the actual lexical, syntactic, phonological, and other choices necessary for the emergence of humour (Attardo 2010 [2008]: 108; Krikmann 2004: 54-63). The theory can be applied separately to all humorous texts, but due to the source material of this article I will focus my analysis on the linguistic level relevant to the material, which has been considered the base level influenced by the others. However, I will still point out the connections between the material and all other levels.

\section{MATERIAL, METHOD OF COLLECTION, AND ANALYSIS}

Children's jokes in the context of pre-schools and the viewpoint of pre-school teachers are in the foreground in the article based on the material obtained from the competition in collecting child lore. The survey plan used for the child lore collection competition of 2011, where participants were asked to give their answers in free format, covered three topics: 1) Festive occasions and parties; 2) Games; 3) Tales and remarks. There was a separate point $\mathrm{C}$ under the third topic: Please observe children for some time and write down any funny remarks they make. This was answered by 45 pre-school employees (teachers, speech therapists) from 34 Estonian-language pre-schools nationwide. The material received consisted of 100 pages of material and 880 children's jokes written down by adults. Shorter responses contained single remarks written down as a result of brief observation, while longer responses contained over 120 texts (e.g. the 129 written recordings from 2001-2010 sent by the teachers of Tartu Kannikese pre-school). ${ }^{4}$

The collection competition confirmed the fact that teachers in many preschool groups have initiated the tradition of writing down the cool and witty remarks of children. Some people have found ways of preparing and publishing collections of these remarks, creating group lore that will always remind the people concerned of the time spent in pre-school. Officially, such material belongs in the child's learning or development portfolio (development folder), which is kept for each child during the time they attend pre-school and which plays an important role in the process of assessing the child's development. Teachers of the Helika pre-school in Tartu mention the emotional value of the collected material in their cover letter, saying that it makes a great gift. The teachers and last-year pre-school children prepared illustrated Lapsesuu (Child's Mouth) 
books, which were given as gifts on the nursery school's birthday or to children leaving pre-school for primary school (ERA, DK 40, 202 (3.C)).

There have also been other child lore collection initiatives and teachers gladly take part in them. The aforementioned cover letter says that two teachers of Helika pre-school in Tartu won the joke competition organised by children's magazine Täheke (Little Star) in 2009 with children's jokes, after which the jokes were published in both Täheke and the compilation Kükitav mannatera (Squatting Manna Grain) (Martson 2010).

A pre-school teacher from Hargla said that the remarks made by children are recorded in a separate notebook to make sure "they are not forgotten" and read out to the children every April Fool's Day, April 1 (ERA, DK 40, 180 (3.C)).

Pre-school teachers generally added no information about naming the phenomenon or terminology. As respondents were asked to write down funny remarks made by children, there was no need for them to use terminology in respect of the phenomenon.

Written recordings are generally divided into two: 1) remarks made during incidental everyday activities and communication; and 2) remarks received in response to targeted questions asked by teachers and their expectations (the teacher has recorded a discussion of a given subject, e.g. the meaning of happiness, what children want to become when they grow up, etc.). In terms of form (which constitutes the narrative strategy in the aforementioned GTVH), written recordings may only be short monologues of anonymous children (e.g. a noteworthy word used by a child with the meaning presented by the teacher) without any description of the external context or situation:

1. A lexical unit to which the meaning of a word or verbal combination has been added.

Müri oli - äike müristas. (There was müri - a noun made up from the verb müristama, to thunder) (ERA, DK 40, 234 (3.C))

2. The remark is presented as direct speech of the child, preceded by the child's first name or first name and age:

Tormi: "Minul on need täitsa uued peksapüksid (teksapüksid)" ("I have these new beat pants (jeans)") (peksapüksid (peksma - beat, püksid pants, trousers) instead of teksapüksid (jeans)) (Sept 2010) (ERA, DK 40, 235 (3.C))

Raio (3): "If I had one leg, I'd know exactly where to put the boot!" (ERA, DK 40, 258 (3.C)) 
3. Often, teachers have written down dialogues between themselves and a child, or between two children, where the joke is evoked by the child's response to the teacher's question or a reaction to some activity:

The teacher asks Markus Sander: "May I help you to peel this mandarin?" Markus Sander asks back: "Do you want to eat the peels?" (ERA, DK 40, $126(3 . \mathrm{C}))$

4. Less often, teachers present narratives with longer contextual descriptions, where the child's remark provides the comical punch line.

A 4-year-old boy was watching a burning candle and, with my permission, started to put it out with a snuffer. He pressed it down too hard on the candle, making hot candle wax drip on the floor and congeal. I said: "Now that's trouble." The boy responded: "That's not trouble; that's an occupational accident”. (ERA, DK 40, 118 (3.C))

This is a case of short folklore, where the narrative description of activity is brief or missing altogether and the child's remarks provide the punch line that creates the comical effect.

In some cases, teachers have added cover letters. A teacher from Priisle preschool in Tallinn has mentioned the importance of the situational context and emphasised that "often, these jokes are only funny in the given situation. The child's facial expressions, body language, etc., also add to this" (ERA, DK 40, 222 (3.C)).

It must be said that the context, the situation (level 3 of the GVTH), the syncretic and multimodal facets of the material are briefly described on the basis of the recorded remarks. However, these details really are important for the emergence of the comical effect, e.g. in the next example, a child sitting with his leg crossed over his knee comes across as comical to the teachers and is an important detail in the emergence of humour:

Raul (4) sits with the teachers in the recreation room, with his leg crossed over his knee, and declares: "Imavere pre-school is a really good preschool!" (ERA, DK 40, 358)

There are many texts whereby the context must be explained by the teacher before its final meaning can be understood:

Agnes (4) calls out to the teacher: "Tule ruttu, Henri hakkab siin majandust tegema!" ("Come quickly, Henri is starting to make economy here!") (majandus - economy, pahandus - mess). (ERA, DK 40, 329) 
This survey is a primary attempt to categorise material. The material can be divided into a system based on content and subject matter, which I have used in the gift book Meie armastuse emmed (Our Beloved Mums) commissioned by Ajakirjade Kirjastus (Voolaid 2012): e.g. family (mums and dads, grandmas and grandpas), nature (plants, animals, birds), people's appearance (beauty), festive occasions, everyday life (eating, getting dressed, playing), abstract phenomena (luck, accident, wealth, etc.). In the case of classification by content and subject matter, a text may belong to several categories at the same time. In her study, Sigrid Schmidt (2005) highlighted four main categories of children's remarks: jokes caused by insufficient language skills, limited knowledge of the adult world, questions, witty answers and reactions. Schmidt's categories are presented from different bases or overlapping: the last to seem to be rather formal, e.g. a child's question or witty answer/reaction may be funny because of insufficient language skills or limited life experience, and also arise from limited knowledge of adult life. According to the GTVH, jokes arising from the insufficient language skills of a child work primarily on linguistic resource; a child's limited knowledge of the adult world may also manifest itself at the level of language, but at the same time reflect the child's understanding of their surroundings and reveal references to the surrounding context, the sociocultural background.

\section{Child humour based on linguistic resource or language humour}

The linguistic level mentioned in the GTVH seems to be the most important factor in the analysis of children's jokes and is primarily expressed here in pronunciation errors, mix-ups by the speaker, such as Freudian slips, malapropisms (the act of using an incorrect word in place of one that is similar in pronunciation, e.g. using similar-sounding foreign words), spoonerisms (a verbal error in which a speaker accidentally transposes the initial sounds or letters of two or more words), etc. One-third of the remarks written down by pre-school teachers are based on the level of word formation, and they create a source of humour based on wordplay in the classic sense. According to Salvatore Attardo, linguistic jokes occur technically in ordinary speech as wordplay, but they differ in their nature from intentional puns, which are also considered linguistic jokes (similar to meta- and poetic language) (see Attardo 1994). Attardo (ibid.) distinguishes four categories of wordplay with similar words: paronyms, homonyms, homographs, and homophones. Paronyms are words that are similar in their phonemic composition (sound), but that are not identically spelt and have different meanings. Homonyms are similar in their phonemic and graphemic 
composition, divided into homographs - words that share the same written form as another word but have a different meaning (row : row), and homophones words that are pronounced the same as other words but differ in meaning, and may differ in spelling (mourning : morning).

One of the main causes of linguistic jokes is the use of a word with similar pronunciation in the wrong meaning, i.e. the lexical intersection of the joke lies mainly in similar words or homonyms and paronyms. Children can mix up words that overlap partly in the morphemic composition. The child uses his or her thoughts, using a word that they have heard and that they associate with the word they are trying to say. Such mistakes sound funny, as they make the listener/reader mentally join two scripts - the one that was said with the one that was meant or intended to be said (see also Nilsen \& Nilsen 2000: 8). Of course, one has to keep in mind that we can usually not speak of intentional linguistic 'comedy' in the case of children, which is why the remarks are better described with neutral linguistic terms (metathesis, paronymy, homonymy with its subtypes homography and homophony) instead of intentional methods of humour (wordplay, such as spoonerism, malapropism, Freudian slip, paranomasia/paranomastic image).

At the lexical level, the replacement of letters in a word is enough to lead to a joke:

Janek (6): "Marjo, kas sul mokamütsi on?" ("Marjo, do you have a lip cap?”; mokamüts - lip cap; nokamüts - billed cap) (ERA, DK 40, 358); there is $m$ alliteration: mokamüts instead of nokamüts.

A grammatical slip of the tongue may also make a word humorous, e.g. choosing the wrong thematic vowel or consonant gradation that the child is unable to use normatively:

We're driving past the Anne rowing canal and 6-year-old Ander says: "Lähme homme siia kanalasse ujuma" ("Let's go swimming in the chicken farm tomorrow”) (ERA, DK 40, 328); (kanal : kanalisse - canal; kanala : kanalasse - chicken farm).

5-year-old Sven Erik heard his teacher and mum speaking about blood sausages and found that: "Seasid tapetakse" (Pigs are killed", the correct form in Estonian would be "sigu”). (ERA, DK 40, 331)

A typical example of a slip of the tongue is the metathesis in the expression kõrge kontsaga kingad or kontsakingad ('high-heeled shoes' or 'heeled shoes'), whereby teachers have written down mistakes on four occasions (and interestingly, all the mistakes have been made by girls): kintsakongad (ERA, DK 40, 
260 (3.C)), konksa kingad (ERA, DK 40, 343); morphological derivation with the same expression has also been recorded: ilusad kontsatatud kingad (ERA, DK 40, 301), kontsad (ERA, DK 40, 304). The material contains other metathetic examples at the level of words, which in the theory of humour are treated as spoonerisms:

Joosep (4): “Teacher! We went to the hallway! SAJALA!!!” (should be salaja - secretly). (ERA, DK 40, 257)

The following jokes, for example, are based on paronomastic formation:

Gerdo tells the girls: "Ma olen saanud kunagi pasteedi peal hüpata!" (“I got to jump on pâté once!") (ERA, DK 40, 357); (pasteet - pâté; batuut trampoline).

Miiu (4): "Minu lemmikloom on amsterdam" ("My favourite animal is amsterdam!” ) (Amsterdam instead of hamster). (ERA, DK 40, 203 (3.C))

Children are eating at the table. Mehis looks out the window at the swirling snow and says: "Purskab väljas!" ("It's bursting outside!") (purskab bursting; tuiskab - snowing heavily). (ERA, DK 40, 354)

The language skills of a child in pre-school are still developing. They often do not have enough words to express themselves, so they have to invent inflections themselves. These are characterised by playfulness and creativity that have their own logic. Children have a command of various mechanisms. A typical one is blending several words or contamination, e.g. the aforementioned kontsad; teachers have twice recorded the use of pillima (to cry) to say pilli mängima (to play a musical instrument) (ERA, DK 40, 83), and klaverit mängima (play the piano) (ERA, DK 40, 180 (3.C)). Morphological derivation, e.g. deriving a verb from a noun, is also characteristic of child language:

Onne Liis goes to the new cleaning corner in the room: "Teen lapi märjaks ja lähen lappima!" ("I'll make the rag wet and go ragging!") (lapp rag, cloth, patch; lappima - to mend something by putting a patch on it). (ERA, DK 40, 354)

Eliise (2) shows her polished nails: "Näe, vaata-Mann küüsis!” ("LookMann nailed!”) (kü̈̈s - nail, kü̈̈sima does not exist). (ERA, DK 40, 358)

Children are sewing. A boy says: “Tüdrukutel tuleb nõelamine paremini välja. ("Girls are better at stinging") (nõelama - to sting; nõel - needle). This is not man's work”. (ERA, DK 40, 170 (3.C)) 
The mechanism also works in the opposite direction - children derive nouns from verbs:

An electrician is working in the room, changing a switch on the wall. Mikael (5): "Kas sa paned meile uue vajutela?” ("Are you installing a new presser?”) (vajutama - to press; lüliti - switch). (ERA, DK 40, 302)

Kirke-Liisa: "Gerdo läheb uisutama uisulasse!” "Gerdo will go skating in the skatery!") (uisutama - to skate). (ERA, DK 40, 357)

Children can be very prolific and creative when forming compound words:

Children are looking at photos of Estonian celebrities. The teacher shows them a photo of the ballerina Kaie Kõrb and asks: "Do you know who Kaie Kõrb is?” Gerly: “Ilukeerutaja!”(“Figure spinner!”). (ERA, DK 40, 356)

The material contains original creations arising from the individual logic of children, who have their own etymology:

Annabel, two, calls the checkout lady in the shop "maksma tädi" ("pay auntie'), because her mum always says in the shop that now we have to pay auntie for the goods. (ERA, DK 40, 330)

Homonymic creation of entirely new words is also common:

"Nü̈̈d ma tean, pull on isa, tal ei ole taguraid!" ("Now I know, a bull is male as he has no udders!") (Tagurad is used instead of udarad). (ERA, DK 40, 315)

"Ema, vaata, kapsutaja tuleb!" ("Look, mum, the teacher is coming!") (kapsutaja is used instead of kasvataja). (ERA, DK 40, 315)

It is known that the teacher who wrote down the last example uses the word kapsutaja as her username in social media and on Skype. In terms of folkloristics and linguistics, it is interesting to note that a child's original (incorrect) linguistic creations can have an emotional effect on an adult's correct language and the wrong form of a word may be used as group slang in a community for years.

The majority of remarks suggest imitation of the correct words heard from adults and repetition of expressions. It feels funny for an adult when children start using the expressions they have heard and place themselves in the world of adults, e.g. use foreign words or opinions that are not age-appropriate. Children's remarks, which are obviously based on a previous description of a situation by an adult, are testament to the connection between the linguistic and contextual levels (manner of speaking and stylistic choices): 
Melinda (3): "An old hag sold Salme [grandma] putrid fish at the market!" (What vocabulary at the age of three!) (ERA, DK 40, 257)

Unexpected style or the use of a figure of speech may also be funny. For example, the use of slang may be unexpected:

Raul is dreaming: "When I grow up, I'll be a rocker; I'll rock hard!" (ERA, DK 40, 356)

Teachers may be surprised by children's knowledge of juicy expressions and imagery. The phraseologisms that children use in their direct sense, unaware of their generally known figurative meaning, can also be sources of jokes:

Marie (6): "Liisa did not come to pre-school today, because she is warm in the head" ('warm in the head' in Estonian means stupid). (ERA, DK 40, 330)

The logic of acquiring the first and second language and the essence of the production process comes from the fact that a person's linguistic ability, the capacity to understand, attribute meaning and store knowledge is based on association and analogue-based generalisation, and it is directly related to the universal ability of self-organisation of the knowledge that is the basis of these processes (Eslon et al. 2010: 27). Many of the written recordings contain mix-ups of words, semantic changes or associations and analogies, which work as mnemotechnical methods in the case of children (children sort of remember something form earlier conversations, but not entirely correctly):

Samuel (5): "We went sleighing in Jõgevapoeg hills" (he is referring to Kalevipoeg Hills near Jõgeva, merging them into Jõgevapoeg Hills). (ERA, DK 40, 202)

Teacher: "What river runs through Tartu?" Ott (6): "Emavesi!" "(Mother Water!") (the correct answer would be Emajõgi - Mother River). (ERA, DK 40, 202)

Repeated associations or linguistic developments that are probably influenced by pop culture (films and books) stand out among the material: for example, many children associate Dalmatian dogs with being black and white, calling black and white cows they see in pastures Dalmatian cows (ERA, DK 40, 12 (3.C)) and referring to a cabbage white butterfly as a Dalmatian butterfly (ERA, DK 40, 16); the TV show Inspector Rex has inspired them to use the name Rex as a synonym for a dog (ERA, DK 40, 11 (3.C)). There are two written records of jä̈̈vhambad (permanent teeth) being called jäähambad (ice teeth), which 
is a typical example of semantic change (jä̈̈v (permanent) is abstract, jää (ice) a concrete category) (ERA, DK 40, 244 (3.C) and ERA, DK 40, 327). This example is associated with the linguistic logic on the basis of which a child derives leivahambad (bread teeth) on the basis of piimahambad (milk teeth) (ERA, DK 40, 359); and it is also logical for a child that neljapäev (Thursday, literally the fourth day) is followed by viiepäev (fifth day; Friday in Estonian is actually reede) (ERA, DK 40, 358); etc.

Bilingualism has sometimes been the source of humour, as it is associated with semantic change and general knowledge, e.g. a child may see the word 'mum' and their mother's name as synonyms:

A girl from a Russian family is asked: "What's your mum called?" “Mamotshka!" (Mum in Russian). (ERA, DK 40, 83)

Many texts illustrate the emphatic anthropomorphic approach of children whereby they liken the nature of surrounding objects to themselves, give life to lifeless objects, attribute feelings to lifeless objects, and so on.

Teacher: "What happens to a tree when rabbits chew off its bark?"

Sigrid: “The tree gets cold!" (ERA, DK 40, 356)

Children may also treat commodities, clothes, footwear, etc., as living beings in their speech.

Maria (4) comes in from outside: "I am all covered in snow and my boots are cold!” (ERA, DK 40, 358)

In the Estonian version of the text, the girl uses the word ümeli instead of üleni when she says she is all covered in snow, which is humorous in itself, but the figurative image is a stronger method of making this sentence funny.

Many written records reflect the sincere attempts of children to justify and describe phenomena and situations on the basis of their experience and logic. Argumentation in these texts is extremely creative considering the limited life experience of children, but it may come across as extremely funny for adults:

Children are playing a guessing game. The teacher describes the object in the picture:

"It's lifeless, round, and black and white."

"A cow," guesses Alvaro.

"I said that it's lifeless," says the teacher.

"A dead cow!" says Alvaro.

(ERA, DK 40, 355) 


\section{Constant references to socio-cultural contexts}

As we broaden the level of linguistic word formation, we see references to the child's socio-cultural experience in the remarks. Folklore emerges in the constant association with the surrounding cultural environment, so we can also say that the remarks made by children are a reflection of the surrounding world and they present genuine versions of this world, which have emerged on the basis of the child's life experience and the logic based on this. Eve Kikas (2010: 140) has pointed out that listening to the speech of adults and interpreting it is very important in the creation of new explanations; adults are the ones who supply words to children by answering their questions and helping them structure information. Unfortunately, the material is too random to make any ground-breaking conclusions about children's views of the world, but it does give an idea of how certain stereotypes are adopted at an early age. Therefore, the corpus contains meaningful reflections of gender stereotypes, the behavioural patterns children imagine a true man would exhibit and their understanding of how femininity is expressed.

Kalle tells the others with an air of importance: "A real man can take the cold!” (ERA, DK 40, 354) (A real man can take anything.)

Raul to Madis-Mairold: "Guess why I don't like bald girls? Because I think then that they're boys!” (ERA, DK 40, 354) (A girl who has short hair or is bald is boyish.)

Having heard a teacher say "Eww!" four-year-old Andri asks: "Are you also some shrieking woman?" (ERA, DK 40, 330) (Women express themselves by shrieking.)

Five-year-old boy: "Women are necessary, because without them there would be no children." (ERA, DK 40, 118 (3.C)) (The importance of a woman's role lies in giving birth and raising children.)

Many of the situations worth writing down arise spontaneously in the course of pre-school activities. The teacher's educational guidance can often be seen in dialogues, followed by the child's unexpected logic and interpretation of the situation:

Mattis (5) has put his hat on so that one flap is tucked in; the other one is hanging loose.

Teacher: "A proper man doesn't go out like this."

Mattis: "Yes he does if he wants to." (ERA, DK 40, 11 (3.C)) 
In jokes, they place themselves in the roles of adults and try to imagine what they would do if they were grown-ups:

Karl (3): "I wish I was already grown up, so I could take myself a real wife." (ERA, DK 40, 330)

The manner in which a child pictures and understands a situation has also been recorded in writing. The next story illustrates a child's genuinely emphatic impression of her father's place of work. The humour arises from the salience of a narrow detail that is incredible for adults (museum employees cannot go out to eat). The reasons why this impression was created remain 'behind the scenes', but would interest the researcher.

Haldi's father is the director of a museum. One day, after eating, Haldi takes two leftover biscuits from the table and says: "I'll take them to the ladies in the museum. They cannot go out to eat. I don't like starving people!” (ERA, DK 40, 357)

The activities of adults, e.g. coffee drinking, also become noteworthy.

Four-year-old Piibe comes to pre-school in the morning and complains to the teacher, who is drinking coffee, that even though she ate at home, she's still hungry. When the teacher asks her if she would like some porridge, Piibe replies: "I don't want porridge, but I'd like some coffee!" (ERA, DK 40, 333)

Children's sense of the world is best revealed in the repertoire that has been received in answer to the targeted questions and expectations of teachers. Teachers have specifically interviewed children and recorded the discussions of some topics, e.g. the whole group's discussion of the meaning of happiness and their opinions of what they would like to be when they grow up. The material is similar to interviews carried out by journalists about topical subjects (e.g. the article about celebrating Easter, written on the basis of an interview carried out in a pre-school (Päärt 2006)), and the targeted interviews carried out by researchers in order to clarify children's attitudes and perspectives regarding certain phenomena or their knowledge about a certain topic (e.g. Kikas 2010; Siim \& Assmuth 2016). Technically, there are not as many linguistic jokes (although the linguistic base level may also be important), as the comedy arises from the difference between ordinary behaviour and the way a child understands the world on the basis of their limited life experience and how they express this understanding.

Interaction with the adult world is well illustrated by a discussion organised by a teacher, where children were asked who they wanted to be when they grow up. 
I am enclosing the survey from 2010, where children were asked who they wanted to be when they grew up. These children were just about to leave preschool for school.

Hester - I want to be a babysitter. I will show up at the door and ask: "Where's the baby?"

Mattias - I will be a writer like my dad! You know, I changed my mind, I will be a general after all!

Simoona - I can't really be bothered to become a doctor. I want to be a shop assistant!

Anita-My mum wants me to be a doctor and I will! I have gentle hands! Jan-Jasper - I want to become a policeman.

Kreete-Lisette - I don't know yet. Maybe a shop assistant... Pet shop assistant! I will change my mind.

Loviisa Lorelai - I want to be a singer. If I cannot be a singer, then I'd like to be an accountant like my mum.

(ERA, DK 40, 226)

Humour arises in situations where the child imagines professions on the basis of their limited contacts with them, and emphasises certain details (e.g. you need gentle hands to be a doctor; or you can work in a pet shop when you become a shop assistant), and jumping suddenly from one thing to another (by naming professions that require cardinally different skills: writer/general, singer/accountant).

In some cases, issues that are very important for adults have been discussed. For example, the topic "How to save money in difficult times?", which was written down in Imavere pre-school in 2009, is clearly inspired by the recession that had hit society at the time:

Don't buy expensive things, like coffee machines.

You can borrow from the bank.

You only have to buy food.

If you have a garden, you can get food from there.

Don't go shopping at all.

Just buy your things and then nothing else.

My dad still has his job; he has money.

(ERA, DK 40, 361/2)

Complicated problems are discussed in pre-schools, and these discussions reflect children's knowledge of specific situations. This example reveals children's attitude towards money (you can borrow from the bank), consumption values 
(children know that present-day coffee machines are expensive, food is of primary importance and it can be grown in a garden), and the topic of unemployment that is closely related to the social environment.

\section{SUMMARY}

The jokes written down by pre-school teachers represent the adult's position and, at the time of writing down, they were more adult than child humour, which made it important to use an interdisciplinary approach in the analysis, depending on the aspect. The way children experience and express things is usually turned into a story and written down by someone else, usually a family member - parent or grandparent, older brother or sister, child-minder, preschool teacher, etc. - who happened to witness the event. Funny remarks meet all the conditions required to become folklore, group or family lore that binds a community, which may continue to spread verbally or in writing or become topical from time to time. Teachers record remarks with a sense of perspective, so the tradition forms an important verbal support to memories saved in baby photo albums and memory books.

The multi-layered records of children's remarks are closely related to humour and jokes in terms of their content, topics, and construction techniques, which is why the entire phenomenon can be analysed via theories of humour. According to theories of humour, remarks are usually accidental incidences of humour that arise in everyday activities, but sometimes they can also be the result of the targeted discussions of topics. The majority of remarks perceived as funny are based on slips of the tongue associated with the language acquisition process and linguistic development of children as well as the process of getting to know the world, which leads to unique and original interpretations. According to the GTVH, which was applied to the material, there are several levels that open and intertwine - the opposition of scripts, malfunctions in logical mechanisms, situationality and context, target of the remark, narrative strategy or genre, and linguistic resources. In accordance with the language acquisition process and linguistic development of children, the main emphasis in the analysis of children's remarks in this study is on the linguistic resource, including humour, where the collision between two opposing scripts is based on the lexical, including homonymic and patronymic, use of words and word formation. This is primarily expressed in pronunciation errors, mix-ups, and associative developments.

Children's remarks also give a rather direct reflection of the surrounding reality. The specific material does now allow for making profound absolute 
conclusions about the child's view of the world, but it does make it possible to identify socio-cultural references, connections in the surrounding environment and constant (concealed) dialogue with the adult world (e.g. acquired cultural stereotypes, imitating the adult world), which can be studied further in the future with the help of additional interviews. It seems that the personality of the moment of recording is not important later on in the case of most jokes and the texts work as humour after the initial situation and context have dispersed.

Giving attention to what children say contests the well-known Estonian proverb, "A child speaks when a hen pees", and attributes importance to the child as a personality and his or her opinions. This approach is characteristic of the strong modern paradigm of childhood sociology, which focuses on the child. It can be said that such lore values little personalities and makes it possible to create emotional connections as the child grows (e.g. reduce the need for recognition during the teenage years), and in ideal cases could help different generations find a common language.

\section{ACKNOWLEDGEMENTS}

Research for this article was supported by the Centre of Excellence in Estonian Studies (CEES, European Regional Development Fund) and is related to research project IUT 22-5 (Estonian Research Council). The author wishes to thank the anonymous reviewers for the valuable comments.

\section{NOTES}

1 The first collection of children's songs (58,832 pages) by Walter Anderson, the widely acclaimed folklorist and first professor of folklore at the University of Tartu, dates back to 1921-1939.

2 Anu Vissel is the only folklorist in Estonia who regarded childlore as a separate field of research at doctoral level in her thesis "Children's Lore in the Changing Society" (Vissel 2004).

3 The plans and materials of the training seminars are available online for officials and teachers engaged in pre-school education at http://folklore.ee/kp/lp/; materials about the nationwide competition in collecting pre-school lore held from 2010-2011 and the questionnaire can be found at http://folklore.ee/kp/lp/index_e.html.

4 All of the material received during the collection competition has been entered in the database http://folklore.ee/Lapsesuu/ (Voolaid 2015), which is password-protected due to ethical reasons. 


\section{ARCHIVAL SOURCES}

ERA, DK - Estonian Folklore Archives, collection of digital manuscripts

\section{REFERENCES}

Argus, Reili 2003. Lastekeelest ja selle uurimisest. [On the Child Language and Its Research.] Oma Keel, No 1, pp. 26-32. Available at http://www.emakeeleselts. ee/omakeel/2003_1/OK_2003-1_03.pdf, last accessed on May 12, 2016.

Argus, Reili 2007. Eesti lastekeelekorpuse morfoloogilisest märgendamisest. [Morphological Coding of Estonian Child Language Database.] In: Pille Eslon (ed.) Tallinna Ülikooli keelekorpuste optimaalsus, töötlemine ja kasutamine. Tallinn: Tallinna Ülikooli kirjastus, pp. 65-86.

Attardo, Salvatore 1994. Linguistic Theories of Humor. Berlin \& New York: Mouton de Gruyter.

Attardo, Salvatore 2010 [2008]. A Primer for the Linguistics of Humor. In: Victor Raskin (ed.) The Primer of Humor Research. Humor Research 8. Berlin \& New York: Mouton de Gruyter, pp. 101-155. DOI: 10.1515/9783110198492.101.

Attardo, Salvatore \& Raskin, Victor 1991. Script Theory Revis(it)ed: Joke Similarity and Joke Representation Model. HUMOR: International Journal of Humor Research, Vol. 4, No. 3/4, pp. 293-347. http://dx.doi.org/10.1515/humr.1991.4.3-4.293.

EKSS 2009 = Langemets, Margit \& Tiits, Mai \& Valdre, Tiia (eds.) Eesti keele seletav sõnaraamat. [Explanatory Dictionary of Estonian.] Vol. 3, L-O, Tallinn: Institute of the Estonian Language. Available at http://www.eki.ee/dict/ekss/ index.cgi?Q=lapsesuu\&F=M, last accessed on May 12, 2016.

Eslon, Pille \& Õim, Katre \& Kaivapalu, Annekatrin \& Argus, Reili \& Matsak, Erika 2010. Kuidas uurida esimese ja teise keele omandamist? [Perspectives of the Research of the First and Second Language Acquisition.] Lähivõrdlusi. Lähivertailuja, Vol. 20, pp. 11-48. DOI:10.5128/LV20.01.

Kharchenko, Vera 2012. Korpus detskikh vyskazyvanii. [Corpus of Children's Remarks.] Moskva: Izdatel'stvo Literaturnogo Instituta im. A. M. Gor'kogo.

Hiiemäe, Mall 2014. Naljakatel eluseikadel rajanevad lood kogukonnapärimuses. [Narratives about Humorous Life Events in the Community Tradition.] Keel ja Kirjandus, No. 11, pp. 845-861. Available at http://kjk.eki.ee/ee/issues/2014/11/558, last accessed on May 12, 2016.

Kikas, Eve 2010. Laste mõtlemine. Pilved, vihm ja vikerkaar laste seletustes. [Children's Thinking: Clouds, Rain, and Rainbow in Children's Explanations.] Mäetagused: Hüperajakiri, Vol. 46, pp. 139-156. DOI:10.7592/MT2010.46.kikas.

Kraav, Inger 2007. Lapse areng valdkonniti ja võimalused sellele kaasa aidata. [Areas of Child Development and How to Help Them.] In: Siiri-Liisi Läänesaar (ed.) Lapsehoidja käsiraamat. Tallinn: Perekasvatuse Instituut, pp. 58-123.

Krikmann, Arvo 2004. Koestler, Raskin, Attardo ja teised: Lingvistiliste huumoriteooriate uuemaist arenguist. [Koestler, Raskin, Attardo and Others: New Developments of Linguistic Theories of Humour.] Reetor 4. Tartu: Eesti Kirjandusmuuseum. 
Kõiva, Mare (ed.) 1995. Lipitud-lapitud: Tänapäeva folkloorist 1. [Contemporary Folklore 1.] Tartu: Eesti Kirjandusmuuseum \& Eesti Keele Instituut.

Laineste, Liisi 2003. Suunad huumori uurimises. [Trends in Humour Research.] Keel ja Kirjandus, No. 11, pp. 793-804. Available at http://www.digar.ee/viewer/et/ nlib-digar:195649/143197/page/3, last accessed on May 12, 2016.

Martin, Rod A. 2007. The Psychology of Humor: An Integrative Approach. Burlington: Elsevier Academic Press.

Martson, Ilona 2010. Kükitav mannatera ja teisi eesti laste nalju. [Squatting Manna Grain and Other Jokes of Estonian Children.] Tallinn: Tänapäev.

Mägiste, Julius 1924. Paar sõna lastekeelest. [Some Words about Child Language.] Eesti Keel, No. 1, pp. 1-9.

Nilsen, Alleen Pace \& Nilsen, Don Lee Fred 2000. Encyclopedia of 20th-Century American Humor. Phoenix: Oryx Press.

Prout, Alan \& James, Allison 2005. A New Paradigm for the Sociology of Childhood? Provenance, Promise and Problems. In: Chris Jenks (ed.) Childhood: Critical Concepts in Sociology I. London \& New York: Routledge, pp. 56-80.

Põldmäe, Rudolf 1941. Eesti rahvanaljandid I: Inimese eluperioodid. [Funny Estonian Folk Tales I: Periods of Human Life.] Tartu: Teaduslik Kirjandus. Available at http://www.folklore.ee/rl/pubte/ee/nali/, last accessed on May 12, 2016.

Päärt, Villu 2006. Lihavõttejänes käib kodus mune peitmas. [Easter Bunny Is Hiding Eggs at Home.] Newspaper Postimees, April 15, p. 6. Available at http://www. postimees.ee/1539573/lihavottejanes-kaib-kodus-mune-peitmas, last accessed on May 12, 2016.

Raskin, Victor 1985. Semantic Mechanisms of Humor. Synthese Language Library 24. Dordrecht \& Boston \& Lancaster: D. Reidel Publishing Company.

Schmidt, Sigrid 2005. Kindermund - Erheiternde Kinderaussprüche und ihr Verhältnis zu Witzen. Folk Narrative Theories and Contemporary Practices: Abstracts. 14th Congress of the International Society for Folk Narrative Research (ISFNR). July 26-31, 2005, Tartu, Estonia. Tartu: Estonian Literary Museum \& University of Tartu, p. 257. Available at http://www.folklore.ee/isfnr/abstracts.php, last accessed on May 12, 2016.

Siim, Pihla Maria \& Assmuth, Laura (forthcoming). Mobility Patterns between Estonia and Finland: What about the Children? In: Kirsti Jõesalu \& Anu Kannike (eds.) Cultural Patterns and Life Stories. Acta Universitatis Tallinnensis, Socialia / Humaniora. Tallinn: Tallinn University Press.

Chukovsky 2001 [1958] = Chukovskii, Kornei. Sobranie sochinenii v 15 t. T. 2: Ot dvukh do piati. [Collected Works in 15 Volumes. Vol. 2: From Two to Five.] Moskva: Teppa - Knizhnyi klub. Available at http://www.chukfamily.ru/Kornei/Prosa/ Ot2do5/Ot2do5.htm, last accessed on May 12, 2016.

Vissel, Anu 2004. Lastepärimus muutuvas ühiskonnas. [Children's Lore in the Changing Society.] Ars Musicae Popularis 15. Tartu: Eesti Kirjandusmuuseumi etnomusikoloogia osakond. Available at http://dspace.ut.ee/handle/10062/1042, last accessed on May 12, 2016.

Voolaid, Piret 2012. Meie armastuse emmed: Lapsesuu räägib. [Our Beloved Mums: Child's Mouth Talks.] Tallinn: Ajakirjade Kirjastus.

Voolaid, Piret 2015. Lapsesuu. [Child's Mouth.] Tartu: Eesti Kirjandusmuuseum. Available at http://www.folklore.ee/Lapsesuu, last accessed on May 12, 2016 (passwordprotected due to ethical reasons). 